\title{
Esensi Peserta Didik dalam Perspektif Pendidikan Islam
}

\author{
MUSADDAD HARAHAP \\ Fakultas Agama Islam (FAI) Universitas Islam Riau (UIR) Pekanbaru \\ Jl. Kaharuddin Nasution, No. 113, Perhentian Marpoyan Pekanbaru 28284 \\ e-mail: musaddad_hrp@yahoo.co.id/musaddadhrp@fis.uir.ac.id
}

\begin{abstract}
Abstrak: Peserta didik adalah manusia seutuhnya yang berusaha untuk mengasah potensi supaya lebih potensial dengan bantuan pendidik atau orang dewasa. Sementara itu, secara terminologi peserta didik berarti anak didik atau individu yang mengalami perubahan, perkembangan sehingga masih memerlukan bimbingan dan arahan dalam membentuk kepribadian serta sebagai bagian dari struktural proses pendidikan. Dengan kata lain peserta didik adalah seorang individu yang tengah mengalami fase perkembangan atau pertumbuhan baik dari segi fisik dan mental maupun fikiran. Sebagai individu yang tengah mengalami fase perkembangan, tentu peserta didik tersebut masih banyak memerlukan bantuan, bimbingan dan arahan untuk menuju kesempurnaan. Setiap peserta didik memiliki eksistensi atau kehadiran dalam sebuah lingkungan, seperti halnya sekolah, keluarga, pesantren bahkan dalam lingkungan masyarakat. Dalam proses ini peserta didik akan banyak sekali menerima bantuan yang mungkin tidak disadarinya. Adapun esensi manusia itu adalah sebagai makhluk ciptaan Allah bukanlah makhluk yang ada dan bereksitensi dengan sendirinya, dan di dalam diri manusia itu terdapat beberapa unsur yaitu unsur al-jism dan al-ruh atau fisik dan psikis. Sehingga, dapat disimpulkan bahwa esensi peserta didik tidak akan bisa untuk diketahui jika mereka tidak mengetahui hakikat atau esensi dari manusia itu sendiri. Kemampuan untuk itu tentu tidak hanya bisa berdiri sendiri tapi haruslah ada bantuan dari orang dewasa, atau bahasa yang lebih teknis pendidikan. Dengan pendidikan inilah peserta didik ditempa, baik terhadap jasmani mapun rohaninya agar semuanya bisa aktif untuk membesarkan dan mengagungkan Allah semata-mata.
\end{abstract}

Kata Kunci: Esensi, Peserta Didik, Pendidikan Islam

\section{PENDAHULUAN}

Dalam Islam peserta didik ialah
setiap manusia yang sepanjang
hayatnya selalu berada dalam
perkembangan, jadi bukan hanya anak-
anak yang sedang dalam pengasuhan
dalam pengasihan orang tuanya, bukan
pula hanya anak-anak dalam usia
sekolah, tetapi mencakup seluruh
manusia baik sebagai individu maupun

sebagai kelompok, baik manusia yang beragama Islam maupun tidak, atau dengan kata lain manusia secara keseluruhan, setiap orang yang terlibat dalam satu kegiatan pendidikan, baik itu formal, informal, maupun non formal harus mampu mengembangkan dan mensosialosasikan berbagai persoalan yang berkaitan dengan peserta didik secara baik dan benar, 
demi terselenggaranya kegiatan pembelajaran yang menyenangkan bagi guru dan juga bagi peserta didik.

Diantara $\begin{gathered}\text { yang } \\ \text { adalah }\end{gathered}$ tentang
diperhatikan bagaimanakah eseensi dari peserta didik, kewajiban dan tugas peserta didik, atau etika peserta didik dalam menuntut ilmu. Untuk menjadi peserta didik yang baik, sebaiknya memiliki dan mengembang sifat-sifat mulia dan meghindari sifat-sifat tercela, sebab sifat-sifat mulia tersebut akan mempermudah peserta didik dalam menuntut ilmu, sebaliknya sifat-sifat tercela akan menghambat peserta didik dalam menuntut ilmu.

\section{KONSEP TEORI \\ Definisi Peserta Didik}

Sebelum membicarakan esensi peserta didik dalam perspektif filsafat pendidikan Islam secara panjang lebar, alangkah baiknya dirumuskan dulu kerangka berpikirnya melalui perumusan arti peserta didik itu. Sebab dengan mengetahui definisi yang mapan terhadap pengertian dua kata ini, tentu tidaklah terjadi kesalahan dalam memberikan penafsiran nantinya ketika membicarakan esensi yang sesungguhnya.

Memang diakui pemberian definisi terhadap suatu objek tidak akan bisa memberikan hasil yang maksimal, dan hal itulah yang terjadi dan membuat para pakar memiliki rumusan yang beragam ketika mendefinisikan apa itu peserta didik. Tapi walaupun begitu setidaknya di awal tulisan dalam makalah ini dengan pemberian definisi tersebut diharapkan akan menjadi dasar untuk mengulas apa yang menjadi substansi persoalan nantinya.

Ada yang berpendapat peseta didik itu adalah manusia yang belum dewasa, oleh karenanya ia membutuhkan pengajaran, pelatihan, dan bimbingan dari orang dewasa atau dengan bahasa yang lebih teknis adalah "pendidik"dengan tujuan untuk mengantarkannya menuju suatu pematangan diri. Dari sudut pandang yang lain, ada juga yang mengatakan bahwa peserta didik itu adalah manusia yang memiliki fitrah atau potensi untuk mengembangkan diri, sehingga ketika fitrah ini ditangani secara baik maka sebagai eksesnya justru anak didik itu nantinya akan menjadi seorang yang bertauhid kepada Allah (Al Rasyidin, 2012: 148).

Sementara itu, bila merujuk kepada Undang-Undang Republik Indonesia Nomor 20 Tahun 2003 tentang SISDIKNAS yang terdapat dalam BAB I Pasal 1 poin keempat, dijelaskan bahwa peserta didik itu adalah anggota masyarakat yang yang berusaha mengembangkan potensi diri melalui proses pembelajaran yang tersedia pada jalur, jenjang, dan jenis pendidikan tertentu.

Maka dari keterangan di atas amat sangat jelas terlihat peserta didik itu maknanya tidaklah hanya dalam tataran pendidikan formal saja, juga tidak memberi batasan usia, dan bahkan tekanannya sangat mejemuk dengan tidak melihat bentuk perbedaan karena mengacu kepada sebuah kesadaran akan kemajemukan bangsa Indonesia itu sendiri. Namun yang paling terpenting dalam pengertian itu adalah istilah "berusaha mengembangkan potensi", itu artinya lewat pendidikan atau proses pembelajaran yang terarah dan positif diharapkan dapat untuk mengoptimalkan potensi para peserta didik itu, baik dalam wilayah pendidikan formal, non formal, informal dan juga pada tataran jenis dan bentuk pendidikannya.

Sejalan dengan apa yang termuat dalam UU SISDIKNAS RI No. 20 Tahun 2003, maka senafas benar apa yang dikemukakan oleh Moh. Roqib, bahwa 
peserta didik adalah semua manusia, yang mana pada saat yang sama dapat menjadi pendidik sekaligus peserta didik (Roqib, 2009: 59). Maka dari itu semakin jelaslah apa yang dimaksudkan dengan peserta didik, yaitu manusia seutuhnya yang berusaha untuk mengasah potensi supaya lebih potensial dengan bantuan pendidik atau orang dewasa.

Setelah mendapatkan gambaran apa yang dimaksud peserta didik, kiranya perlu juga untuk dijelaskan sepintas bahwa kata kunci peserta didik dikalangan masyarakat kita sangat variatif, hal ini dipahami sebagai penjabaran dari SISDIKNAS, misalkan: Siswa/Siswi"istilah bagi peserta didik pada jenjang pendidikan dasar dan menengah",

Mahasiswa/Mahasiswi"istilah umum bagi peserta didik pada jenjang pendidikan tinggi yaitu perguruan tinggi ataupun sekolah tinggi", Warga belajar "istilah bagi peserta didik yang mengikuti jalur pendidikan nonformal. Misalnya seperti warga belajar pendidikan keaksaraan fungsional", Pelajar" istilah lain yang digunakan bagi peserta didik yang mengikuti pendidikan formal tingkat dasar maupun pendidikan formal tingkat menengah", Murid "istilah lain peserta didik", "Santri"istilah bagi peserta didik di pesantren atau sekolah-sekolah salafiyah yang dijiwai oleh ajaran Islam".

Kemudian menurut hemat penulis istilah-istilah di atas patut untuk direnungkan terutama kaitannya dengan SISDIKNAS kita, artinya ketika disebutkan peserta didik apa berarti istilah yang lain dianggap telah terwakili di dalamnya atau sebaliknya, artinya penggunaan istilah ini sangat umum. Logika berpikirnya kelihatannya begitu, walaupun memang secara konten pembelajarannya satu sama lain berbeda tapi prinsip-prinsip dasarnya secara umum tidak berbeda, yaitu sama-sama pembelajar yang terikat oleh regulasi-regulasi yang ada.Mungkin disebabkan inilah yang membuat pemerintah membuat formulasi bahwa peserta didik adalah anggota masyarakat yang berusaha mengembangkan potensi.

Namun bila mengacu kepada penggunaan bahasa sehari-hari peserta didik itu sering disebut sebagai murid, pelajar dan anak didik. Pemakaian istilah bagi ini masyarakat awam mungkin tidak ada persoalan. Tapi justru bila pendekatannya menggunakan kaca mata ilmiah, istilahistilah tersebut ternyata memiliki perbedaan yang sangat mendasar. Hal ini sesuai dengan gagasan yang dikemukakan oleh Tafsirbahwa istilah penyebutan terhadap manusia usia bersekolah itu bukanlah peserta didik seperti yang termuat dalam Sistem Pendidikan Nasional Tahun 2003, tapi istilah yang tepat adalah murid (Tafsir, 2008: 164).

Memang kesannya istilah murid ini akan mengembalikan pendidikan kita terhadap masa tradisi guru sentris, tapi menurutnya tidaklah ada persoalan jika guru dan murid meresapi dan mengamalkannya karena diyakini akan lebih mempercepat dan tepat menghasilkan lulusan yang menjadi manusia. Pandangan ini didasari oleh sebuah keyakinan ilmiah, bahwa istilah murid ini mengandung kesungguhan belajar, memuliakan guru, keprihatinan guru terhadap murid. Dalam istilah murid ini terkandung makna mendalam bahwa mengajar dan belajar adalah sebuah kewajiban. Dalam perbuatan belajar mengajar itu ada berkah. Pendidikan yang dilakukan memenuhi unsur-unsur profan dan transendental (Tafsir, 2008: 165).

Istilah murid ini dari pandangan Tafsir benar-benar dipengaruhi oleh ajaran Islam itu sendiri yaitu 
menekankan kesungguhan belajar, menyucikan diri, kepatuhan murid terhadap guru dan sedang berjalan menuju Tuhan. Disinilah letak mendasar perbedaan istilah murid ini dengan istilah-istilah yang lain. Apalagi penggunaan istilah ini juga jauh sebelum sekarang telah diperkenalkan oleh kalangan sufi. Pada akhirnya kelebihan dalam istilah murid ini jauh lebih terasa dibandingkan dengan istilah lain. Apalagi bila dikaitkan dengan kondisi pelajar sekarang, yaitu terjadinya perosotan capaian subtansi pendidikan yaitu menjadi sosok manusia berakhlak yang mulia. Dengan demikian pada tahap ini akan semakin memperkuat relavansi penggunaan dari istilah ini (Tafsir, 2008: 165-166).

Dari berbagai uraian di atas, telah memberi gambaran-gamabaran teoritis, dan dalam diskursus ini adalah suatu keniscayaan sebab membicarakan esensi peserta didik dalam Islam tidak bisa dilepaskan dari bagaimana cara pandang manusia terhadap manusia, barulah kemudian melihat bagaimana cara pandang Islam tentang manusia itu sendiri. Memang disadari dalam kajian diawal tidaklah banyak didiskusikan pendapat-pendapat tokoh filsuf ternama yang pernah membicarakan manusia seperti, Plato, Socrates, Aristoteles dan sebagainya, namun persoalan yang diangkat hanya sekedar pada wilayah-wilayah yang sering menjadi perdebatan dalam tataran praktek pendidikan dan kondisi masyarakat kita. Jadi dapatlah dipastikan pengenalan atas semua istilah itu tidak terlalu berlebihan, karena fokus pengkajian ini tentu lebih banyak membicarakan manusia secara teorits dari pada manusia secara teknis.

Sementara peserta didik secara terminologi adalah anak didik atau individu yang mengalami perubahan, perkembangan sehingga masih memerlukan bimbingan dan arahan dalam membentuk kepribadian serta sebagai bagian dari struktural proses pendidikan. Dengan kata lain peserta didik adalah seorang individu yang tengah mengalami fase perkembangan atau pertumbuhan baik dari segi fisik dan mental maupun fikiran.

Sebagai individu yang tengah mengalami fase perkembangan, tentu peserta didik tersebut masih banyak memerlukan bantuan, bimbingan dan arahan untuk menuju kesempurnaan. Hal ini dapat dicontohkan ketika seorang peserta didik berada pada usia balita seorang selalu banyak mendapat bantuan dari orang tua ataupun saudara yang lebih tua. Dengan demikian peserta didik merupakan barang mentah (raw material) yang harus diolah dan dibentuk sehingga menjadi suatu produk pendidikan dan tetap mengacu kepada prinsip dasar pendidikan tersebut secara benar dan terarah.

Berdasarkan hal tersebut secara singkat dapat dikatakan bahwa setiap peserta didik memiliki eksistensi atau kehadiran dalam sebuah lingkungan, seperti halnya sekolah, keluarga, pesantren bahkan dalam lingkungan masyarakat. Dalam proses ini peserta didik akan banyak sekali menerima bantuan yang mungkin tidak disadarinya.

Dengan diakuinya keberadaan seorang peserta didik dalam konteks kehadiran dan keindividuannya, maka tugas dari seorang pendidik adalah memberikan bantuan, arahan dan bimbingan kepada peserta didik menuju kesempurnaan atau sesuai dengan kedewasaannya. Dalam konteks ini seorang pendidik harus mengetahuai ciri-ciri dari peserta didik tersebut.

Adapun ciri-ciri peserta didik ialah: (a) kelemahan dan ketak berdayaannya; (b) berkemauan keras untuk berkembang; dan (c) ingin 
menjadi diri sendiri (memperoleh kemampuan) (Ahmadi \& Uhbiyati, 2006: 40). Sedangkan kriteria peserta didik ialah: (a) peserta didik bukanlah miniatur orang dewasa tetapi memiliki dunianya sendiri; (b) peserta didik memiliki periodasi perkembangan dan pertumbuhan; (c) peserta didik adalah makhluk Allah yang memiliki perbedaan individu baik disebabkan oleh faktor bawaan maupun lingkungan dimana ia berada; (d) peserta didik merupakan dua unsur utama jasmani dan rohani, unsur jasmani memiliki daya fisik, dan unsur rohani memiliki daya akal hati nurani dan nafsu; dan (e) peserta didik adalah manusia yang memiliki potensi atau fitrah yang dapat dikembangkan dan berkembang secara dinamis (Ramayulis, 2006: 77).

Didalam proses pendidikan seorang peserta didik yang berpotensi adalah objek atau tujuan dari sebuah sistem pendidikan yang secara langsung berperan sebagai subjek atau individu yang perlu mendapat pengakuan dari lingkungan sesuai dengan keberadaan individu itu sendiri. Sehingga dengan pengakuan tersebut seorang peserta didik akan mengenal lingkungan dan mampu berkembang dan membentuk kepribadian sesuai dengan lingkungan yang dipilihnya dan mampu mempertanggung jawabkan perbuatannya pada lingkungan tersebut.

Sehingga agar seorang pendidik mampu membentuk peserta didik yang berkepribadian dan dapat mempertanggungjawabkan sikapnya, maka seorang pendidik harus mampu memahami peserta didik beserta segala karakteristiknya. Adapun hal-hal yang harus dipahami adalah: (1) kebutuhannya; (2) dimensi-dimensinya; (3) intelegensinya; dan (4) kepribadiannya (Ramayulis, 2006: 78).

\section{Konsep Manusia Menurut Islam}

Dalam memahami manusia tentu harus dipedomani dengan pandangan Islam sebagai tolak ukur yang mendasar untuk mengetahui sesungguhnya apa hakikat manusia. Mesikpun nantinya disela-sela pembahasan, dengan tolak ukur pandangan terdapat persamaan dengan gagasan manusia sebagai pemikir dan pemerhati pendidikan, justru hal itu akan menambah perbendaharaan dan pemahaman tentang konsep manusia, dan akan menjadi modal berharga untuk menghasilkan model pendidikan yang tepat terhadap manusia.

Dalam Alqur'an terdapat beberapa term atau istilah yang merujuk kepada kata manusia. Misalkan, dengan kata alBasyar, yang secara etimologi berarti kulit kepala, wajah, atau tubuh yang menjadi tempat tumbuhnya rambut. Adapun makna-makna yang terkandung dalam al-Basyar ini kadang digunakan dalam arti mulamasah atau persentuhan kulit laki-laki dan perempuan, kadang juga digunakan dalam penjelasan terhadap eksistensi Rasul dan Nabi, juga Allah menggunakannya untuk menjelaskan proses kejadiannya (dalam hal ini kejadian Nabi Adam) (Nizar, 2002: 2). Jadi dengan demikian, ini semua menunjukkan bahwa penyebutan manusia dengan al-Basyar konteksnya adalah selalu merujuk sebagai makhluk biologis, dan rincian itu jugalah salah satunya perbedaan mendasar manusia dengan hewan, terutama subtansi makna kata yaitudimana pada hewan itu yang lebih tampak adalah bulunya, sementara manusia yang lebih tampak adalah kulitnya bukan bulunya seperti pada hewan (Al Rasyidin, 2012: 15).

Terkadang Alqur'an dalam menyebutkan manusia dengan kata alNas, dengan makna penunjukan manusia itu sebagai makhluk sosial secara keseluruhan atau dengan kata 
lain menyebutkan manusia keturunan Adam secara totalitas. Terkadang kata al-Nas digunakan Allah untuk menyebutkan manusia adalah makhluk yang tidak memiliki ketetapan keimanan yang kuat, kadang beriman kadang munafik (Nizar, 2002: 13-16).

Selain dari pada itu, juga Alqur'an menggunakan kata al-Insan untuk menyebutkan manusia, yang secara etimologi berarti harmonis, lemah lembut, tampak dan pelupa. Kemudian maknanya kadang digunakan Allah untuk menunjukkan bahwa manusia itu adalah makhluk jasmani dan rohani, dengan kedua inilah manusia akan bisa naik derajatnya ketingkat yang tinggi, menjadi makhluk Allah yang unik dan istemwa, sempurna, atau sebagai makhluk dinamis sehingga akan mampu untuk memikul predikat khalifah Allah di muka bumi. Dikesempatan lain alInsan digunakan untuk menjelaskan sifat umum, serta sisi-sisi kelebihan dan kelemahan manusia. Kemudian alInsanjugadigunakan untuk menunjukkan proses kejadian manusia sesudah Adam dan juga al-Insan mengandung makna kesempurnaan, sesuai dengan tujuan penciptaannya.

Selain ketiga di atas, ada juga kata yang digunakan untuk menunjukkan manusia yaitu Bani Adam yang artinya generasi keturunan Adam. Ini menunjukkan bahwa manusia itu samasama memiliki harkat dan martabat kemanusiaan yang universal (Al Rasyidin, 2012: 15).

Dari sebutan lain yang digunakan Allah untuk menjelaskan manusia di atas, maka bisa diambil kesimpulan bahwa menurut konsep ajaran Islam manusia pada hakikatnya, adalah makhluk ciptaan Allah yang secara biologis diciptakan melalui proses pertumbuhan dan perkembangan yang berlangsung secara evolutif dan variatif, yaitu melalui proses yang bertahap. Sebagai makhluk ciptaan, manusia memiliki bentuk yang lebih baik, lebih indah dan lebih sempurna dibandingkan makhluk lain ciptaan Allah, hingga manusia dinilai sebagai makhluk lebih mulia, sisi lain manusia merupakan makhluk yang mampu mendidik, dapat dididik, karena manusia dianugerahi sejumlah potensi yang dapat dikembangkan. Itulah antara lain gambaran tentang pandangan Islam mengenai hakikat manusia, yang dijadikan acuan pandangan mengenai hakikat peserta didik dalam pendidikan Islam (Jalaluddin, 2003: 144).

Dengan demikian manusia bukanlah makhluk yang berdiri sendiri tapi ia adalah makhluk yang didirikan. Dalam hal ini Alquran telah memberikan keterangan secara impilisit bahwa manusia tersebut bukanlah makhluk yang ada (being) dan berada (existence) dengan sendirinya, tapi manusia diciptakan oleh Tuhan dengan melalui tiada menjadi ada (Adam) dan lewat proses yang kompleks (manusia keturunan Adam).

Dalam pandangan Islam manusia tercipta dari dua unsur yaitu unsur materi dan non materi. Dari pengertiannya bahwa dimensi materi bermakna manusia adalah al-jism dan dimensi non-materi bermakna al-ruh (Al Rasyidin, 2012: 6). Adapun kedua dimensi tersebut harus betul-betul diperhatikan dalam praktek pendidikan, karena Islam sangat menghargai kedua dimensi tersebut. Mengintegrasikan keduanya dalam pendidikan Islam harga mati. Keduanya harus sejalan dan tidak boleh tumpang tindih. Jika pendidikan tidak mengambil perannya menyentuh kedua ranah itu, maka manusia akan tertinggal dan tidak akan mampu mengenali rahasia-rahasia diri, padahal menyingkap rahasia dibalik diri adalah langkah yang tepat untuk mengenali Pencipta diri. Pengungkapan rahasia keunikan diri 
manusia juga akan mengantarkan manusia kepada sebuah kesadaran sehingga akan berdaya guna untuk menambah wawasan dalam mengurus dan menjaga alam semesta ciptaan Tuhan.

Sementara kedua dimensi yang ada dalam diri manusia ini menurut Harun Nasution disebut dengan unsur materi dan imateri atau "jasmani dan ruhani", yaitu tubuh manusia berasal dari tanah dan ruh atau jiwa berasal dari subtansi imateri di alam gaib. Tubuh pada akhirnya akan menjadi tanah dan ruh atau jiwa akan pulang ke alam gaib. Lebih lanjut Harun Nasution memaparkan bahwa unsur-unsur penciptaan manusia itu sesungguhnya memiliki daya-daya (Nasution, 1989: 37).

Jism merupakan struktur manusia yang merupakan organisme fisik. Bila dibandingkan dengan makhluk lainnya,seperti hewan dan tumbuhan maka bentuk organisme manusia lebih sempurna. Secara prinsipil manusia jelas-jelas berbeda dengan hewan, meskipun antara manusia dengan hewan banyak kemiripan terutama jika dilihat dari segi biologisnya. Bentuknya (misalnya dengan orang hutan), tapi hal itu tidak mengharuskan manusia sama dengannya, karena ada hal-hal yang memisahkannya keduanya berbeda total, seperti dijelaskan Anwar Hafid dkk bahwa manusia berbeda dengan hewan karena manusia itu memiliki kemampuan menyadari diri, kemampuan bereksistensi, pemilikan kata hati, moral, kemampuan bertanggung jawab, rasa kebebasan (kemerdekaan), kesediaan melaksanakan kewajiban dan menyadari hak, dan kemampuan menghayati kebahagian, tapi hal ini tidaklah dimiliki oleh hewan atau tumbuhan (Hafid, 2013: 2).

Jism manusia atau dimensi material ini sesungguhnya telah dijelaskan oleh Allah dalam Alqur'an dalam Surah Al-Mukminun ayat 12-16 bahwa manusia itu berasal dari tanah, dan dalam hadis pun telah dijelaskan bagaimana tahap-tahap perkembangannya, sehingga akhir dari jism ini akan menjadi tanah pula. Namun yang paling terpenting disini adalah esensi dari jism itu. Harun Nasution menjelaskan jism ini memiliki daya-daya yaitu daya fisik dan jasmani, di antaranya mendengar, melihat, merasa, meraba, mencium, dan juga ada daya gerak misalnya bisa menggerakkan tangan, kepala, kaki, mata, dan sebagainya. Kemudian manusia itu juga bisa pindah tempat seperti pindah tempat duduk, keluar rumah dan sebagainya atau bahasa yang lebih teknis adalah jism ini memiliki dua daya yaitu daya fisik atau jasmani dan daya gerak (Nasution, 1989: 37).

Sturuktur lain adalah ruh, masalah ini telah digariskan dalam AlQur'an yang menyebutkan setelah kejadian manusia dalam kandungan mengambil bentuk, ditiupkanlah ruh oleh Allah dan dijadikan-Nya pendengaran, penglihatan dan perasaan. Allah SWT berfirman:
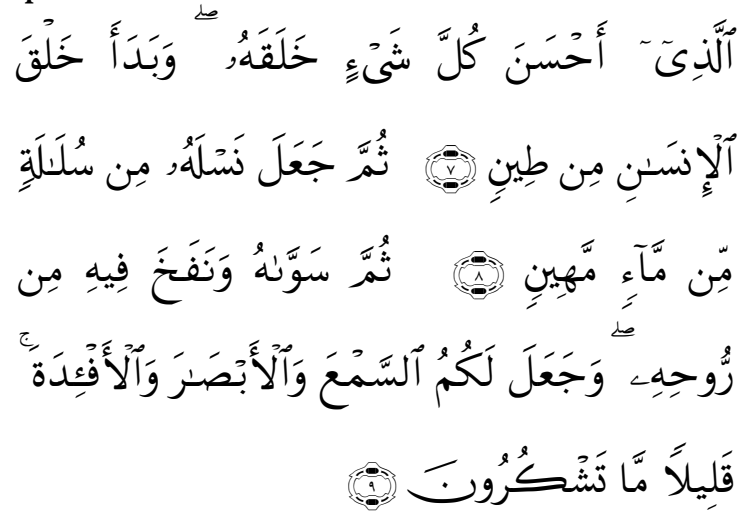

Artinya: "Yang membuat segala sesuatu yang Dia ciptakan sebaikbaiknya dan yang memulai penciptaan manusia dari tanah. Kemudian Dia menjadikan keturunannya dari saripati air 
$\begin{array}{lr}\text { yang hina. Kemudian } & \text { Dia } \\ \text { menyempurnakan } & \text { dan } \\ \text { meniupkan ke dalamnya } & \text { roh } \\ \text { (ciptaan)-Nya dan Dia } & \text { Dia } \\ \text { menjadikan bagi kamu }\end{array}$ pendengaran, penglihatan dan hati; (tetapi) kamu sedikit sekali bersyukur". (Q.S. alSajadah, 32: 7-9)

Harus Nasution juga meyakini bahwa ayat itu merupakan sebuah bukti adanya dimensi ruh manusia. Kemudian lebih lanjut dikatakannya bahwa unsur ruh ini juga memiliki daya-daya sebagaimana halnya unsur jism di atas. Daya pertama adalah daya berpikir yang disebut dengan aql yang berpusat dikepala dan daya rasa dinamakan qalb yang berpusat di dada (Nasution, 1989: 37).

Sementara itu Muhammad Naquib Al-Attas sebagaimana $\mathrm{Al}$ Rasyidin mengutipnya mengatakan bahwa manusia itu dilengkapi dengan fakultas yang memiliki sebutan berlainan dalam keadaan yang berbeda, yaitu ruh, nafs, qalb, dan aql. Artinya ketika ruh ini bergelut dengan segala sesuatu yang berkaitan dengan intelektual dan pemahaman, maka ia disebut 'intelek' atau 'aql', ketika mengatur tubuh, ia disebut jiwa "nafs", ketika sedang mengalami pencerahan intuisi ia disebut dengan hati "qalb", dan ketika kembali ke dalam dunianya yang abstrak, ia disebut "ruh" (Al Rasyidin, 2012: 18). Tampaknya apa yang dijelaskan Harun Nasution dengan AlAttas ini tidak begitu berbeda, hanya Al-Attas menganalisisnya lebih dalam dan pembagiannya lebih rinci. Namun pada hakikatnya kedua pendapat ini meyakini bahwa manusia dalam konsep Islam memiliki dimensi jism dan ruh.

Dengan demikian maka al-ruh ini memiliki peran yang sangat menentukan dalam mengarahkan manusia untuk memiliki dan menampilkan suatu perilaku atau tindakan. Ditambah lagi dengan kenyataan bahwa al-ruh inilah yang memerintahkan al-jism untuk menampilkan suatu amal atau perbuatan, sehingga ia disebut dengan hakikat manusia yang sebenarnya.

Setelah itu, pada dasarnya tujuan penciptaan manusia itu pada awalnya Allah hanya meminta kesaksian kepada manusia ketika berada dalam alam al$r u h$ atas kebesaran dan keesaan-Nya. Kesaksian pertama bukan kepada jism tapi kepada al-ruh, sehingga dalam konteks ini, kesaksian manusia merupakan bukti pengenalan dan kesadaran diri manusia akan keberadaan Tuhan, dan inilah salah tujuan penciptaannya. Agar tidak mudah melupakan kesaksian itu, maka Allah menganugerahkan kepada mereka potensi al-sama', al-abshar, dan al-afidah. Dari itu, manusia itu hanyalah makhluk atau 'abdyang diciptakan untuk mengabdi, Allah SWT berfirman:

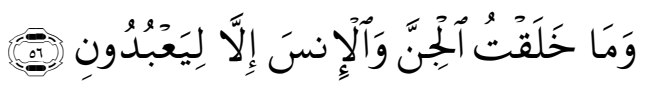

Artinya: "Dan aku tidak menciptakan jin dan manusia melainkan supaya mereka mengabdi kepada-Ku". (QS. Al-Zariyat, 51: 56)

Dalam arti sempit ibadah itu merupakan tugas-tugas pengabdian manusia secara individual sebagai hamba Allah. Tugas ini diwujudkan dengan melaksanakan ibadah-ibadah ritual secara ikhlas dan penuh pengharapan ridha Allah. Namun dalam arti luas, ibadah meliputi segala aktivitas manusia selama hidup di bumi ini, mulai dari hal sederhana sampai kepada yang kompleks, dari yang kecil sampai yang besar. Perlu digaris bawahi bahwa setiap aktivitas ibadah dalam arti luas ini hendaknya tujuan akhirnya pencarian ridha Allah. 
Selanjutnya penciptaan manusia selain makhluk pengabdi, manusia itu juga diisyaratkan memiliki tugas yang lebih berat, yaitu sebagai Khalifah. Allah SWT berfirman:

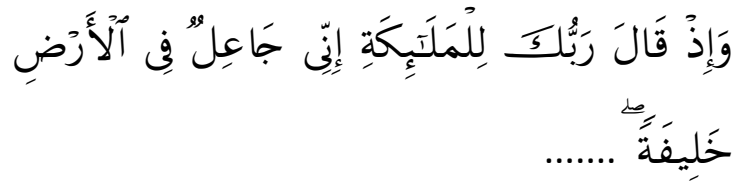

Artinya: "Ingatlah ketika Tuhanmu berfirman kepada Para Malaikat: "Sesungguhnya aku hendak menjadikan seorang khalifah di muka bumi." (QS. Al-Baqarah, 2: 30).

Pengertian Khalifah ini pada mulanya berarti yang menggantikan atau yang datang sesudah siapa yang datang sebelumnya. Karenanya, ada yang memaknai kata khalifah dalam arti menggantikan Allah dalam menegakkan kehendak-Nya dan menerapkan ketetapan-ketetapan-Nya, tetapi bukan kerena Allah tidak mampu melaksanakannya, namun karena Allah bermaksud menguji manusia dan memberinya penghormatan. Maka oleh sebab itu kehkalifaan itu terdiri dari: (1) Adanya wewenang yang dianugerahkan Allah; (2) Adanya makhluk yang diserahi wewenang; dan (3) Adanya wilayah tempat bertugas, yaitu bumi (Al Rasyidin, 2012: 27).

$$
\text { Maka dari itu dapatlah }
$$

disimpulkan bahwa tujuan filosif penciptaan manusia ini adalah untuk mengenal Tuhan dan bersyahadah kepada-Nya. Bukti pengenalan dan syahadah manusia terhadap Tuhan itu harus ditunjukkan dalam pelaksanaan fungsi dan tugas manusia sebagai 'abd Allah dan Khalifah-Nya di alam semesta.

Untuk itu, perlu diperjelas beberapa diskripsi tentang hakikat manusia sebagai peserta didik dan implikasinya terhadap pendidikan Islam, yaitu: (1) Peserta didik bukan miniature orang dewasa, akan tetapi memiliki dunianya sendiri. Hal ini sangat penting untuk dipahami, agar peserta didik itu tidak disamakan dengan orang dewasa, baik dalam aspek metode, materi, sumber, sumber bahan pembelajaran yang digunakan; (2) Peserta didik adalah manusia yang memiliki diferensiasi priodesasi pertumbuhan dan perkembangan. Pemahaman ini cukup penting untuk diketahui agar aktivitas kependidikan Islam disesuaikan dengan tingkat pertumbuhan dan perkembangan peserta didik untuk menuju kesempurnaan; (3) Peserta didik adalah manusia yang memiliki kebutuhan, yang menyangkut kebutuhan jasmani dan rohani yang harus dipenuhi; (4) Peserta didik adalah makhluk Allah yang memiliki perbedaan individual, baik yang disebabkan oleh faktor pembawaan maupun lingkungan. Dengan pemahaman terhadap perbedaan ini, diharapkan bisa meminimalisir kegagalan pendidikan yang dilakukan; (5) Peserta didik merupakan resulta dari dua unsur utama, yaitu jasmani dan rohani. Itu artinya kedua aspek ini harus terpenuhi ketika ingin meberikan pendidikan; (6) Peserta didik adalah manusia yang memiliki potensi yang dapat dikembangkan dan berkembang secara dinamis. Untuk itulah orang dewasa atau pendidik harus berperan untuk membantu perkembangan itu kearah yang lebih baik (Nizar, 2002: 40-50).

\section{Esensi Peserta Didik}

Untuk mengetahui esensi peserta didik sumber ajaran agama Islam tentu menjadi dasar pemikiran yang tidak bisa lepas dari pengkajian. Sebab agama adalah fitrah yang diberikan Allah SWT dalam kehidupan manusia, sehingga tatkala seorang peserta didik mengalami masa tumbuh dan perkembangan, sesungguhnya ia telah 
memiliki rasa iman. Namun rasa iman ini akan berubah seiring dengan perkembangan usia peserta didik. Ketika seorang peserta didik keluar dari masa kanak-kanak, maka iman tersebut akan berkembang, ia mulai berfikir siapa yang menciptakan saya, siapa yang dapat melindungi saya, siapa yang dapat memberikan perlinungan kepada saya. Namun iman ini dapat menurun tergantung bagaimana ia beribadah. Oleh sebab itu pendidikan sangat besar peranannya untuk menumbuh kembangkan serta mengembalikan manusia pada tujuan dasarnya.

Dalam perspektif filsafat pendidikan Islami, semua makhluk pada dasarnya adalah peserta didik. Sebab, dalam Islam, sebagai murabbi, mu'allim, atau muaddib, Allah pada hakikatnya adalah pendidik bagi seluruh makhluk ciptaan-Nya. Dialah yang mencipta dan memelihara seluruh makhluk. Pemeliharaan Allah mencakup sekaligus kependidikan-Nya, baik dalam arti tarbiyah, ta'lim, maupun ta'dib. Karenanya, dalam perspektif filsafat pendidikan Islam, peserta didik itu mencakup seluruh makhluk Allah, seperti malaikat, jin, manusia, tumbuhan, hewan, dan sebagainya.

Namun, dalam arti khusus peserta didik adalah seluruh al-insan, al-basyar, atau bani adam yang sedang berada dalam proses perkembangan menuju kepada kesempurnaan atau suatu kondisi yang dipandang sempurna (alinsan al-kamil). Terma al-Insan, albasyar, atau bani adam dalam definisi ini memberi makna bahwa kedirian peserta didik itu tersusun dari unsurunsur jasmani, ruhani, dan memiliki kesamaan universal seperti yang telah dikemukakan pada bagian terdahulu, yakni sebagai makhluk yang diturunkan atau dikembangbiakan dari Adam kemudian, terma perkembangan dalam pengertian ini berkaitan dengan proses mengarahkan kedirian peserta didik, baik dari fisik (jism) maupun diri psikis (ruh) aql, nafs, qalbagar mampu menjalankan fungsi-fungsinya secara sempurna (Al Rasyidin, 2012: 148-149). Jadi, peserta didik sebagai makhluk Allah yang diberi tugas untuk memakmurkan bumi, justru diberi kelebihan dan juga keistimewaan yang tidak diberikan kepada makhluk lain, yakni kecerdesan akal, dan kepekaan hati yang mampu berpikir rasional dan merasakan sesuatu di balik materi dan perbuatan. Keutamaan yang lain yang diberikan Allah kepada manusia adalah fitrah, yakni potensi manusawi yang educable. Dengan bekal itulah memungkinkan bagi manusia untuk mencapai taraf kehidupan yang amat tinggi dalam aspek peradaban dan kedekatan dengan Allah (Roqib, 2009: 59).

Dalam Widodo Supriyono juga dijelaskan bahwa secara garis besar manusia itu ada dua dimensi seperti halnya pendapat-pendapat lain di atas, yaitu dimensi al-jismdan al-ruh. Ia menyatakan bahwa secara alruhmanusia mempunyai potensi kerohanian yang tak terhingga banyaknya. Potensi-potensi tersebut nampak dalam bentuk memahami sesuatu (ulil albab), dapat berfikir atau merenung, memepergunakan akal, dapat beriman, bertaqwa, mengingat, atau mengambil pelajaran, mendengar firman Allah, dapat berilmu, berkesenian, dan sebagainya (Supriono, 1996: 171).

Oleh karena itu, potensi-potensi yang dikaruniakan oleh Allah itulah yang menjadi sasaran dari pendidikan Islam. Bagaimanakah pendidikan Islam supaya bisa untuk mengembangkan potensi-potensi itu sehingga bisa lahir manusia-manusia yang punya pengalaman, keterampilan, kecakapan, keprofesionalan tapi yang pada akhirnya manusia itu akan sadar betapa besar dan kuasanya Tuhan. Bahkan 
bukan sebaliknya ketika manusia sudah pada puncak kejayaan yang paling tinggi mereka lupa dan mengingkari Tuhan, hal itu tidaklah dikendaki oleh Pendidikan Islam.

Memang pendidik dalam Islam pada hakikatnya adalah Allah, namun dalam batas-batas tertentu manusia juga diberi mandat ke khalifaan atau manusia diberi kebebasan untuk memberi pendidikan kepada sesamanya karena mereka adalah makhluk yang dinamis dan dibekali dengan potensi yang cukup potensial. Sehingga pendidik itu adalah orang dewasa, artinya adalah orang yang lebih berpengetahuan, berpengalaman, dibandingkan yang didik.Untuk itu pendidikan yang diberikan kepada peserta didik, harus bersesuaian dengan apa yang sudah digariskan oleh Allah dan kesanalah arah pendidikan Islam itu.

Peserta didik memang memiliki daya dan potensi untuk berkembang dan siap pula untuk dikembangkan. Karena itu, setiap peserta didik tidak dapat diperlakukan sebagai manusia yang sama sekali pasif, seperti yang dipercayai oleh kaum emprisme, melainkan peserta didik itu memiliki kemampuan dan keaktifan yang mampu membuat pilihan dan penilaian, merima, menolak atau menemukan alternative lain yang lebih sesuai dengan pilihannya sebagai perwujudan dari adanya kehendak dan kemauan bebasnya (Siddik, 2011: 67).

Bila peserta didik dibiarkan tumbuh dan berkembang secara alamiah tanpa bantuan pendidikan, hal itu sangat memungkinkannya kehilangan arah dalam menempuh perjalanan menuju kebaikan dan kebenaran. Al-Attas juga mengakui hal demikian bahwa manusia bisa menjadi baik harus dengan pendidikan, dengan pendidikan inilah lahir manusia universal atau insal kamil (Al-Attas,
1990: 10). Karena kalau tidak, peserta akan cenderung disesatkan oleh berbagai pengaruh dari lingkungan yang datang dari luar dirinya. Apalagi sebuah kenyataan bahwa peserta didik itu punya sarana kemampuan untuk menerima pengaruh yang menyesatkan dan/atau menyelematkan (positif dan negatif), sama-sama tersedia di dalam diri manusia. Seperti telah dikemukakan di awal bahwa penyebutan Alqur'an terhadap manusia dengan kata al-nas salah satu indikasinya adalah manusia itu pelupa, sering salah, imannya tidak tetap, kadang kuat terkadang tidak. Ketika keadaan imannya tidak tentu pembiaran peserta didik untuk berkembang dan tumbuh secara alamiah dapat dipastikan akan terjadi konsekuensi negatif yang akan merugikan peserta didik itu. Allah SWT berfirman:

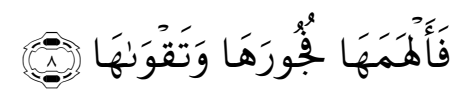

Artinya: "Maka Allah mengilhamkan kepada jiwa itu (jalan) kefasikan dan ketakwaannya" (Al-Syams, 91: 8).

Dari ayat di atas membuktikan bahwa pendidikan itu sangat urgen dalam kehidupan umat manusia untuk menumbuhkan sisi positif yang ada dalam dirinya tersebut untuk mencapai kesempurnaan.

Adapun yang dimaksud kesempurnaan adalah suatu keadaan di mana dimensi jismiyah dan ruhiyah manusia itu (peserta didik), melalui proses tarbiyah, ta'lim, maupun ta'dib, diarahkan secara bertahap dan berkesinambungan untuk mencapai tingkatan terbaik dalam kemampuan mengaktualisasikan seluruh daya atau kekuatannya. Berdasarkan sudut pandang demikianlah seluruh unsurunsuru anggota jasmani manusia atau peserta didik harus mencapai 
tingakatan terbaik dalam kemampuannya dalam melakukan tugas-tugas fisikal-biologis, seperti bergerak, berpindah, dan melakukan berbagai aktivitas fisikal lainnya. Demikian pulalah halnya dengan dimensi ruhiyah yang terdiri dari aql, nafs, dan qalb peserta didik, lewat pendidikan harus bisa mencapai tingakatan terbaik dalam berpikir atau menalar, dalam mengendalikan dan mensucikan diri, dan dalam menangkap cahaya dan memahami kebenaran. Sehingga terbentuklah manusia sempurna seutuhnya atau insan kamil.

\section{Tugas Dan Tanggung Jawab Seorang Peserta Didik}

Sesuai dengan karakter dasarnya, ilmu itu datangnya dari Allah dan karenanya ia merupakan al-nur atau cahaya kebenaran yang akan menerangi kehidupan para pencarinya. Sebagai al-haq, Allah Maha Suci, dan kesuciannya hanya bisa dihampiri oleh yang suci pula. Karenanya, sifat utama dan pertama yang harus dimiliki peserta didik adalah mensucikan diri atau jiwanya (tazkiyah) sebelum menuntut ilmu pengetahuan. Karena maksiat hanya akan mengotori jasmani, akal, jiwa dan hati manusia, sehingga membuatnya sulit dan terhijab dari cahaya, kebenaran, atau hidayah Allah (Zainuddin \& Nasir, 2010: 111-113). Sejalan dengan penjelasan ini Al-Attas mengemukakan bahwa sebetulnya orang-orang muslim sepakat bahwa semua ilmu itu datangnya dari Allah. Dimana kedatangannya kepada fakultas-fakultas jiwa serta indera yang menerima dan menafsirkannya tidaklah sama (Al-Attas, 1990: 42). Artinya pensucian jiwa dan jasmani harus betul-betul diperioritaskan karena ilmu adalah milik Allah dan dari Dialah asalnya. Memang manusia dalam menerima dan menafsrikannya tidaklah sama, namun itulah yang menjadi tugas pendidikan Islam agar kedua dimensi yang telah disepakati beserta subtansi yang terdapat di dalamnya tetap terpelihara dari berbagai gangguan dan noda yang akan membuat daya-dayanya terkikis dan melemah.

Nah, agar pelaksanaan proses pendidikan Islam dapat mencapai tujuan yang dikehendaki untuk menjadikan peserta didikinsane kamil, maka setiap peserta didik hendaknya senantiasa menyadari tugas dan tanggung jawabnya. Seperti dikemukakan oleh Al-Abrasyi sebagaimana dikutif Al Rasyidin, bahwa di antara tugas-tugas dan tanggung jawab peserta didik itu antara lain: (1) Sebelum memulai aktivitas pembelajaran, peserta didik harus terlebih dahulu membersihkan hatinya dari sifat yang buruk, karena belajarmengajar itu merupakan ibadah dan ibadah harus dilakukan dengan hati dan jasmani yang bersih; (2) Peserta didik belajar harus dengan maksud mengisi jiwanya dengan berbagai keutamaan untuk mendekatkan diri kepada Allah; (3) Bersedia mencari ilmu ke berbagai tempat yang jauh sekalipun, meskipun harus meninggalkan daerah tempat kelahiran atau tanah air, keluarga, saudara atau bahkan ayah dan ibu dan sebagainya; (4) Tidak terlalu sering menukar guru, dan hendaklah berpikir panjang sebelum menukar guru; (5) Hendaklah menghormati guru, memuliakannya, dan mengagungkannya karena Allah serta berupaya menyenangkan hatinya dengan cara yang baik dan diridhai oleh Allah; (6) Jangan merepotkan guru, jangan berjalan di hadapannya, jangan duduk di tempat duduknya, dan jangan mulai berbicara sebelum diizinkannya; (7) Jangan membukakan rahasia kepada guru atau meminta guru membukakan rahasia, dan jangan pula menipunya; (8) Bersungguh-sungguh dan tekun dalam 
belajar; (9) Saling bersaudara dan mencintai antara sesama peserta didik; (10) Peserta didik harus terlebih dahulu memberi salam kepada guru dan mengurangi percakapan di hadapannya; dan (11) Peserta didik hendaknya senantiasa mengulangi pelajaran, baik di waktu senja dan menjelang subuh atau antara waktu Isya' dan makan sahur (Al Rasyidin, 2012: 153-154).

Selain itu seperti dikutif Tafsir, Sa'id Hawa menjelaskan tugas murid atau sifat-sifat murid dalam pendidikan Islam harus memenuhi kriteria sebagai berikut: (1) Harus mendahulukan kesucian jiwa sebelum lainnya. Masalah kebersihan jiwa ini dianalogikan seperti halnya shalat, tidak sah shalat jika tidak suci dari hadats maupun najid. Ini artinya menyemarakkan hati terhadap ilmu tidak sah bila mana hati itu kotor dan tidak suci dari akhlak tercela; (2) Mengurangi keterikatannya dengan kesibukan duniawi, karena kesibukan semacam ini akan melengahkannya dari cita-cita dasar dari menuntut ilmu. Jika pikiran tidak terkonsentrasi maka tidak akan dapat memahami hakikat ilmu. Pikiran yang terpancar pada berbagai hal adalah seperti sungai yang airnya terpancar kemudian sebagiannya diserap tanah, sebagian lainnya akan lebih mudah menguap ke udara sehingga tidak dapat memberikan dampak positif terhadap ladang tanaman; (3) Tidak sombong terhadap orang yang berilmu dan tidak bertindak sewenang-sewenang terhadap guru. Patuh terhadap guru ibarat patuhnya pasien terhadap dokter yang mengobatinya. Keterikatan ini harus benar-benar dimiliki peserta didik, karena guru itu adalah tugas mulia yang dimandatkan oleh Allah kepada manusia; (4) Menjaga diri dari perdebatan-perdebatan atau khilafiyah karena akan mengganggu dan membingungkannya. Hal ini dimaksudkan untuk menjaga konsentrasi dalam mempelajari hal-hal pokok dan mendasar. Setelah mapan dan matang tahap selanjutnya tidak masalah; (5) Menekuni ilmu yang paling penting untuk dirinya. Pada tahap ini peserta didik idealnya harus dibimbing dan diarahkan oleh orang yang lebih berpengalaman. Apalah zaman sekarang disiplin ilmu benar-benar cukup kompleks; (6) Tidak menekuni banyak ilmu sekaligus, melainkan berurutan dari yang paling dasar dan penting. Dalam pendidikan Islam yang paling mendasar pengenalan terhadap Allah SWT; (7) Tidak tergesa-gesa menguasai ilmu. Konsisten terhadap ilmu yang sedang dipelajari dan tidak berpindah sebelum rampung tahap ke tahap yang lain; (8) Punya keahlian dalam memilih atau menentukan dimana ilmu yang paling utama dan mulia. Sikap semacam ini merupakan hasil dari proses belajar yang sungguhsungguh. Karena pada dasarnya ilmu bertahap dan berurutan atau sering disebut dengan istilah sistematis (Tafsir, 2008: 167-168).

Tugas dan tanggung jawab seorang peserta didik yang lebih terperinci dan potensial yang tujuannya untuk keberhasilan proses pendidikan bisa dijumpai seperti yang dikemukakan oleh Imam Abu Hamid AlGazhali, sebagaimana terdapat dalam penelitian tesis Asari (2012: 129-146), sebagaimana berikut: (1) Seorang peserta didik harus membersihkan jiwa dari sifat-sifat jelek dan karakter yang buruk seperti pemarah, rakus, sombong, egois, atau yang semacamnya. Maka oleh sebab itu hendaknya harus senantiasa menekankan belajar adalah ibadah spiritual; (2) Seorang peserta didik adalah memusatkan perhatiannya secara penuh kepada studinya dan jangan sampai terganggu oleh urusanurusan duniawi. Konsentrasi adalah sebuah kemestian. Maka dalam proses pembelajaran hendaknya harus mampu 
mengurangi hal-hal yang tidak ada kaitannya dengan belajar itu sendiri; (3) Seorang peserta didik harus menghormati guru. Dia harus tunduk dihadapan gurunya dan mematuhi setiap perintahnya. Peserta didik hendak banyak bertanya tapi dengan syarat harus tetap punya adab yang baik terhadap gurunya. Adapun penghormatan kepada guru ini sebetulnya dilihat hanya sebagai bagian dari penghormatan terhadap pengetahuan dan sangat esensial dalam pendidikan Islam; (4) Peserta didik wajib untuk menghindarkan diri dari keterlibatan dalam kontroversi dan pertentangan akademis yang tidak bermafaat dan berfaedah; (5) Seorang peserta didik mesti berupaya maksimal mempelajari setiap cabang pengetahuan yang terpuji dan memahami tujuannya masing-masing; (6) Kewajiban dan tanggung jawab yang keenam dan ketujuh adalah peserta didik mesti memperhatikan dan mencermati sekuens logis dari disiplindisiplin ilmu yang sedang digelutinya dan kemudian mempelajarinya berdasarkan skuens logis tersebut; (7) Sementara kewajiban kedelapan adalah bahwa peserta didik memastikan kebaikan dan nilai dari disiplin ilmu yang sedang di tekuni atau yang ingin dia tekuni; (8) Kewajiban kesembilan adalah merumuskan tujuan belajar secara benar. Tujuan ini haruslah penyucian jiwa dan pendekatan diri kepada Allah. Seorang tidak boleh menuntu ilmu untuk tujuan duniawi seperti kekuasaan, pengaruh dikalangan penguasa, atau sekedar membangakan diri sendiri, yang semuanya itu akan ada manfaatnya sama sekali. Oleh sebab itu seorang peserta didik harus mengetahui bahwa siapapun yang menuntut ilmu dengan tujuan demi Allah, maka dia pasti akan mendapat manfaat dan kemajuan dalam studinya; dan (9) Kewajiban kesepuluh adalah peserta didik mempertimbangkan dengan sungguh-sungguh hubungan antara cabang-cabang pengetahuan yang dia pelajari dengan tujuan akhirnya. Untuk tujuan ini dia perlu mengetahui klasifikasi pengetahuan. Dia harus mesti mengetahui yang paling penting bagi pencapaian tujuannya.

Maka dengan demikian belajar bukanlah aktivitas yang mudah untuk dilakukan. Meskipun seorang peserta didik telah mendatangi sejumlah guru dan banyak membaca buku, namun hasil belajar yang baik belum tentu bisa dicapai. Belajar juga bukan hanya mengandalkan kehadiran dalam arti fisik, tetapi harus disertai dengan kemauan, kesadaran, kesabaran, dan masih banyak lagi sifat-sifat lain yang idealnya dimiliki setiap peserta didik. Dalam perspektif Islam, kepemilikan sifat-sifat yang juga merupakan tugas dan tanggung jawab peserta didik itu merupakan persyaratan untuk mempermudah jalannya proses pembelajaran, berhasilnya pencapaian tujuan, berkahnya ilmu pengetahuan, dan kemampuan mengamalkan ilmu dalam kehidupan (Al Rasyidin, 2012: 154).

\section{SIMPULAN}

Dari berbagai deretan penjelasan di atas maka penulis mengambil kesimpulan bahwa esensi peserta didik tidaklah bakalan bisa untuk diketahui jika tidak mengetahui hakikat atau esensi dari manusia itu sendiri. Sebab peserta didik dalam Islam adalah manusia dalam arti sempit, dan semua makhluk dalam arti luas, dan hakikat manusia itulah yang harus betul-betul untuk dipahami sehingga dalam menangani para peserta didik tidak terjadi kesalahan yang pada akhirnya akan membawa dampat negatif dikemudian hari. 
Adapun esensi manusia itu adalah sebagai makhluk ciptaan Allah, dia bukanlah makhluk yang ada dan bereksitensi dengan sendirinya, dan di dalam diri manusia itu terdapat beberapa unsur yaitu unsur al-jism dan al-ruh atau fisik dan psikis dengan kata jasmani dan rohani. Nah, jasmani dan rohani sama-sama memiliki daya yang merupakan sebagai bentuk apresiasi Allah terhadap manusia, karena dengan itulah manusia akan bisa berbeda dengan makhluk yang lainnya, misalkan binatang, syetan, malaikat, tumbuhtumbuhan dan sebagainya.

Kemudian dengan pemberian potensi-potensi itu baik potensi jasmani maupun rohani semuanya sebetulnya pemberian Allah agar manusia itu tidak terlalu mudah untuk melupakan kesaksian yang pernah ia proklamirkan di alam arwah. Karena tujuan manusia itu diciptakan bukanlah sesuatu yang sia-sia belaka, tapi manusia diciptakan untuk mengabdi kepada Allah dan membesarkan-Nya. Sehingga dengan potensi itulah manusia akan mampun untuk memenuhi itu semua.

Kemampuan untuk itu tentu tidak hanya bisa berdiri sendiri tapi haruslah ada bantuan dari orang dewasa, atau bahasa yang lebih teknis pendidikan. Dengan pendidikan inilah peserta didik ditempa, baik ia jasmani mapun rohaninya agar semuanya bisa aktif untuk membesarkan dan mengagungkan Allah semata-mata.

Dengan demikian hakikat peserta didik itu adalah individu yang membutuhkan bantuan agar mereka dapat mengenal Allah yang menciptakan mereka, sehingga mereka dalam setiap aktivitasnya senantiasa selalu berada di jalan Allah yang dirihdoi.

\section{DAFTAR RUJUKAN}

Ahmadi, Abu dan Uhbiyati, Nur. 2006. Ilmu Pendidikan. Jakarta: PT Rineka Cipta.

Al Rasyidin. 2012. Falsafah Pendidikan Islami: Membangun Kerangka Ontologi, Epistimologi, dan Aksiologi Praktik Pendidikan. Bandung: Citapustaka Media Perintis.

2009. Percikan Pemikiran Pendidikan.

Bandung:

Citapustaka Media Perintis.

Al-Attas, Syed Muhammad Naquib. 1990. Konsep Pendidikan Dalam Islam. Terj. Haidar Bagir. Bandung: Mizan.

Asari, Hasan. 2012. Nukilan Pemikiran Klasik, Gagasan Pendidikan Abu Hamid Al-Ghazali. Medan: IAIN Press.

Hafid, Anwar dkk., 2013. Konsep Dasar Ilmu Pendidikan. Bandung: Alfabeta.

Jalaluddin. 2013. Teologi Pendidikan. Jakarta : Raja Grafindo Persada.

Mahmud. 2011. Pemikiran Pendidikan Islam. Bandung: Pustaka Setia.

Nasution, Harun. 1989. Islam Rasional. Jakarta: Mizan.

Nizar, Samsul. 2002. Filsafat Pendidikan Islam, Pendekatan Historis, Teorits, dan Praktis. Jakarta: Ciputat Pers.

Ramayulis. 2006. Ilmu Pendidikan Islam. Jakarta: Kalam Mulia.

Roqib. Moh., 2009. Ilmu Pendidikan Islam, Pengembangan Pendidikan Integratif di Sekolah, Keluarga, dan Masyarakat. Yokyakarta: LkiS.

Siddik, Dja'far. 2011. Konsep Dasar Ilmu Pendidikan Islam. Bandung: Citapustaka Media Perintis.

Supriono, Widodo. 1996. Filsafat Manusia dalam Islam, Reformasi Filsafat Pendidikan Islam. Yogyakarta: Pustaka Pelajar. 
Tafsir, Ahmad. 2008. Filsafat Pendidikan Islam, Integrasi Jasmani, Rohani dan Kalbu Memanusiakan Manusia. Bandung: Remaja Rosdakarya.

Undang-Undang Republik Indonesia Nomor 20 Tahun 2003 tentang SISDIKNAS \& Peraturan Pemerintah Republik Indonesia
Tahun $2010 \quad$ Tentang Penyelenggaraan Pendidikan Serta Wajib Belajar. 2010. Bandung: Citra Umbara.

Zainuddin dan Mohd. Nasir. 2010. Filsafat Pendidikan Islam. Bandung: Citapustaka Media Perintis 